\title{
Physical violence and verbal abuse against nurses working with risk stratification: characteristics, related factors, and consequences
}

\author{
Violência física e verbal contra enfermeiros da classificação de risco: características, \\ fatores relacionados e consequências \\ Violencia física y verbal contra enfermeras de clasificación de riesgo: características, \\ factores relacionados y consecuencias
}

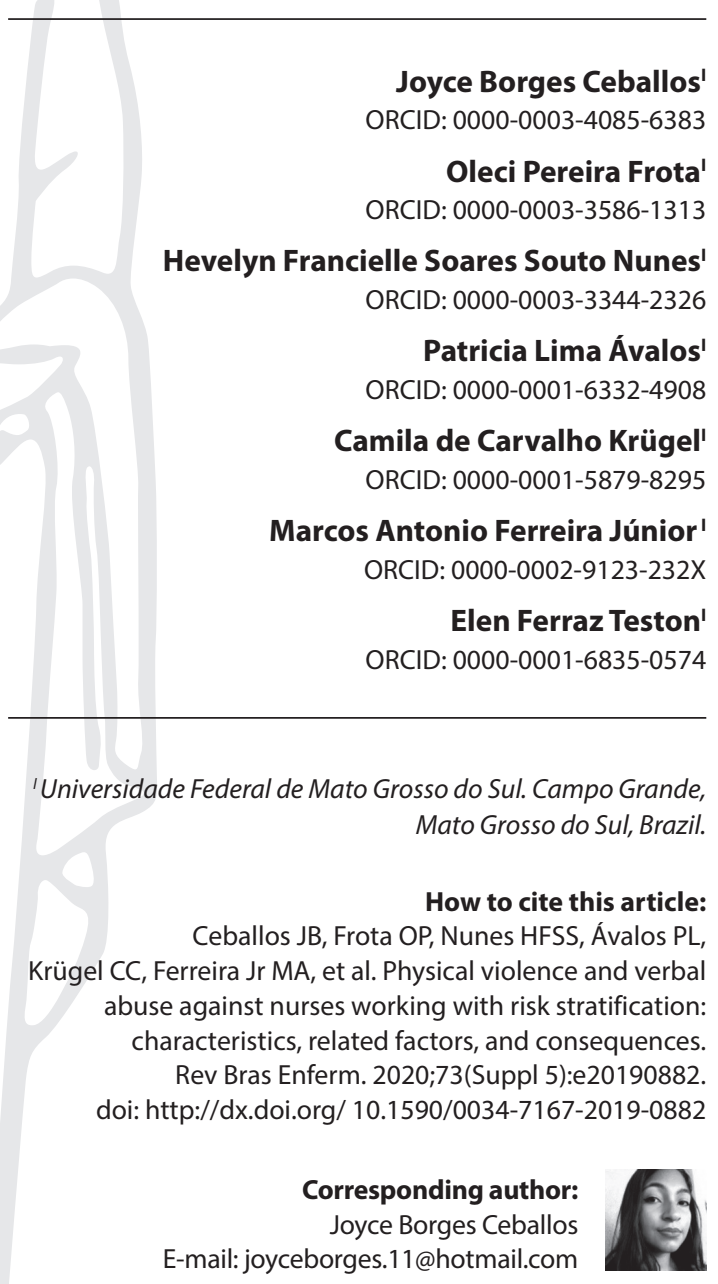

EDITOR IN CHIEF: Antonio José de Almeida Filho ASSOCIATE EDITOR: Ana Fátima Fernandes

Submission: 03-14-2020

Approval: 06-11-2020

\section{ABSTRACT}

Objective: to analyze the characteristics, related factors, and consequences of physical violence and verbal abuse against nurses working with risk stratification. Methods: a crosssectional, descriptive and quantitative study carried out with 80 nurses who work with risk stratification in emergency services. Data were collected using an adapted instrument and analyzed using (uni)bivariate inferential statistics. Results: companions were the main perpetrators of verbal abuse (86.1\%); and patients inflicted physical violence (100\%). Professionals with up to five years of experience are $74 \%$ less likely to suffer physical violence $(p=0.029)$. Women suffer 5.83 times more verbal abuse than men $(p=0.026)$. Sadness $(15.8 \%)$ and fear of the aggressor (15.3\%) were the main consequences of verbal abuse; and fear of the aggressor $(22.2 \%)$ and stress $(22.2 \%)$ were results of physical violence. Conclusion: violence is influenced by institutional, professional and client aspects. Therefore, coping with it requires multidimensional strategies.

Descriptors: Risk Factors; Workplace Violence; Emergencies; Triage; Nurses.

\section{RESUMO}

Objetivo: analisar as características, os fatores relacionados e as consequências da violência física e verbal contra enfermeiros que atuam na classificação de risco. Métodos: estudo transversal, descritivo, com abordagem quantitativa, realizado com 80 enfermeiros que atuam na classificação de risco em serviços de emergência. Os dados foram coletados por meio de instrumento adaptado, e analisados por estatística inferencial (uni)bivariada. Resultados: os acompanhantes foram os principais perpetradores de violência verbal $(86,1 \%)$, e os pacientes, de física (100\%). Profissionais com até cinco anos de atuação têm $74 \%$ menos chances de sofrer violência física $(p=0,029)$. Mulheres sofrerem 5,83 vezes mais violência verbal do que homens $(p=0,026)$. Tristeza $(15,8 \%)$ e medo do agressor $(15,3 \%)$ foram as principais consequências da violência verbal; medo do agressor $(22,2 \%)$ e estresse $(22,2 \%)$ foram resultado da violência física. Conclusão: a violência sofre influência de aspectos institucionais, profissionais e da clientela. Portanto, seu enfrentamento requer estratégias multidimensionais.

Descritores: Fatores de Risco; Violência no Trabalho; Emergências; Triagem; Enfermeiras e Enfermeiros.

\section{RESUMEN}

Objetivo: analizar las características, los factores relacionados y las consecuencias de la violencia física y verbal contra las enfermeras que trabajan en la clasificación de riesgos. Métodos: estudio descriptivo, transversal, con enfoque cuantitativo, realizado con 80 enfermeras que trabajan en la clasificación de riesgos en los servicios de urgencias. Los datos fueron recolectados usando un instrumento adaptado, y analizados usando estadísticas (uni) bivariadas inferenciales. Resultados: los compañeros fueron los principales autores de la violencia verbal $(86,1 \%$ y los pacientes, físicos $(100 \%)$. Los profesionales con hasta cinco años de experiencia tienen un $74 \%$ menos de probabilidades de sufrir violencia física $(p=0.029)$. Las mujeres sufren 5.83 veces más violencia verbal que los hombres $(p=0.026)$. La tristeza (15.8\%) y el miedo al agresor (15.3\%) fueron las principales consecuencias de la violencia verbal; el miedo al agresor (22.2\%) y el estrés (22.2\%) fueron los resultados de la violencia física. Conclusión: la violencia está influenciada por aspectos institucionales, profesionales y del cliente. Por lo tanto, enfrentarlo requiere estrategias multidimensionales.

Descriptores: Factores de Riesgo; Violencia Laboral; Urgencias Médicas; Triaje; Enfermeras y Enfermeros. 


\section{INTRODUCTION}

Workplace violence and harassment are defined by the International Labour Organization (ILO) - Convention 190 - as a set of behaviors, practices or threats, occurring once or repeatedly, that cause, aim at, or are likely to result in physical, psychological, sexual or economic damage to the worker ${ }^{(1)}$. Although they are (sub)classified in several ways, a general categorization divides violent practices between physical violence and verbal abuse. Physical violence can be defined as the "use of physical force against another person or group, which produces physical, sexual or psychological damage", including hitting, kicking, stabbing, throwing, pushing, biting or pinching ${ }^{(2)}$.Verbal abuse, on the other hand, is any form of mistreatment, either explicitly spoken or implied, that causes feelings of devaluation or humiliation, through words in a derogatory tone, threats, accusations or disrespectful expressions, and behavior that suggests physical aggression, but without contact with the victim ${ }^{(3)}$.

In the health field, emergency services such as 24-hour Emergency Care Units and hospitals are places of high risk for occurrence of workplace violence, especially for professionals dealing with patient risk category stratification ${ }^{(4)}$. Based on specific criteria of morbidity and mortality, signs and symptoms, exams, and others, nurses are the workers in charge of welcoming patients and establishing the priority of their care. Thus, they stand in the frontline of care services ${ }^{(5)}$ and are, therefore, more vulnerable to episodes of violence than other professionals ${ }^{(6)}$. Despite this, studies on this subject, focused on the risk category stratification environments, are still scarce in the literature.

Data reveal that, worldwide, about $36.4 \%$ of nurses suffer physical violence, and $67.2 \%$ of them suffer non-physical forms of abuse ${ }^{(7)}$. In Brazil, an investigation carried out by the Regional Nursing Council of São Paulo (Conselho Regional de Enfermagem de São Paulo) identified that $77 \%$ of nursing professionals were victims of workplace violence and harassment. Of them, $49.2 \%$ suffered verbal abuse and $14.2 \%$ suffered physical violence ${ }^{(8)}$. It is noteworthy that workplace violence and harassment have several negative consequences. They involve both damage to the quality of provided care and physical, psychological(9) and financial suffering to professionals. In addition, it negatively impacts organizational functioning, as it generates high professional turnover and job dissatisfaction ${ }^{(10)}$.

In this context, it is reiterated that, although it is a frequent event, workplace violence is underestimated in patient risk category stratification environments. Thus, identifying related factors can become an important starting point for the formulation of more assertive coping strategies, such as public health policies and the promotion of workplace health and safety.

\section{OBJECTIVE}

This study aims at analyzing the characteristics, related factors, and consequences of physical violence and verbal abuse against nurses working in patient risk category stratification.

\section{METHODS}

\section{Ethical aspects}

The ethical requirements established in Resolution 466/2012 of the Brazilian National Health Council (Conselho Nacional de
Saúde) were met. Participants signed the Informed Consent Form (ICF). The research project was approved by the Research Involving Humans Ethics Committee of Universidade Federal do Mato Grosso do Sul.

\section{Design, period, and place of study}

This is a cross-sectional descriptive study of quantitative approach, guided by STROBE, carried out in the city of Campo Grande, state of Mato Grosso do Sul, Brazil. Data were collected from December 2018 to July 2019 in all 24-hour Emergency Care Units (ECU) ( $n=6)$; all 24-hour Regional Health Centers (RHC) $(n=4)$; and in Emergency Care Rooms (ECR) $(n=3)$ linked to the three largest hospitals in the municipality: university, regional, and Santa Casa (Santa Casa is a brotherhood whose mission is to treat and support the sick and invalids, in addition to assisting "exposed" newborns abandoned in the institution), which provide care to the public Brazilian Health System (Sistema Único de Saúde, abbreviated SUS). RHC are prehospital components, specific to the city of Campo Grande, that offer services similar to ECU. However, they do not follow specific legislation, differing from ECU in terms of workflows, physical structure and functioning. They are usually located next to the Basic Health Units.

The university hospital has 232 beds and is a reference in infectious diseases, cardiovascular care and highly complex procedures. The regional hospital has 352 beds and is a reference in high-risk pregnancies, pediatrics, oncology and cardiovascular care. The Santa Casa Hospital has 495 SUS beds, and is a reference in urgency and emergency, orthopedics, treatment of major burns, neurosurgery and transplants.

\section{Population, inclusion and exclusion criteria}

The population comprised all nurses who worked on the patient risk category stratification of the investigated units, in the morning, afternoon and night shifts ( $n=161)$. In turn, nurses working with risk stratification for less than one year $(n=44)$ were excluded; likewise, the study excluded those who refused to participate $(n=29)$; who were on vacation or leave $(n=4)$; or that were not found after three attempts $(n=4)$. The final sample consisted of 80 nurses.

\section{Study protocol}

Before applying the data collection instrument, each professional was instructed on the research objectives by three previously-trained researchers, in each work shift. Filling in the data collection instrument took nurses ten minutes on average, and the participants did it in their workplaces.

For data collection, a questionnaire adapted from a previous study, with the author's permission, was used ${ }^{(11)}$. These adaptations aimed at meeting the peculiarities of the researched population (nurses, as the original instrument was for health professionals at large) and for both types of phenomena under study (physical violence and verbal abuse, as the original instrument investigated physical, verbal, moral and sexual harassment). The final version of the instrument was composed of two parts. The first one presents the definition of workplace violence and harassment 
and questions of sociodemographic characterization, of work identification, and referring to violence.

Sociodemographic variables were sex, age, education level (undergraduate or graduate) and marital status. Length of professional experience, length of work with patient risk category stratification in the institution, weekly workload in risk stratification, work shift (morning, afternoon or night), and the type of healthcare institution (ECU, RHC or ECR-hospital) were workplace identification variables. As for violence at work, the questionnaire addressed the following questions: (i) the importance of workplace violence in the institution, according to the professional's perception (very important, important, moderately important or unimportant); (ii) whether violence is normal and/or is part of the job (yes or no); (iii) a scale from zero to ten regarding the feeling of security in the work environment, where zero corresponded to no feeling of security and ten to a completely safe environment; (iv) what are the most important risk factors for exposure to workplace violence in risk category stratification (several alternatives and the "other reasons" option, with space for a descriptive answer).

The second part of the instrument included questions about experienced physical violence and verbal abuse. It consisted of ten questions that identify nurses' experiences both in relation to physical violence and verbal abuse in the institution, in the last 12 months. The number of times the professional suffered them was included; who was the aggressor; time the act took place; the reaction to the incident; the measures taken; the repercussions on personal and professional life; and if there was leave from the service.

\section{Result analysis and statistics}

The data were analyzed using descriptive and inferential statistics. To verify the association between sociodemographic variables (sex, age, education level, marital status) and professional ones (length of professional experience, length of work with risk category stratification in the institution, work shift, and healthcare institution where they work) with the occurrence of physical violence and verbal abuse in the last 12 months, the chi-square test or Fisher's exact test was applied. Odds Ratio (OR), with a $95 \%$ confidence interval $(\mathrm{Cl})$, was used to estimate the magnitude of associations. In assessing the feeling of security in the workplace (from zero to ten), it was found that the data had non-normal distribution by the Kolmogorov Smirnov test. Thus, when comparing this variable with the occurrence of physical violence and verbal abuse, the Mann-Whitney non-parametric statistical test was applied. The adopted level of significance was $5 \%$. The statistical software used was the Statistical Package for the Social Science (SPSS) for Windows, version 25.0.

\section{RESULTS}

The sample consisting of 80 nurses was mostly female; with an average age of 35.9 years $( \pm 7.1)$; they are married $(51.3 \%$; $\mathrm{n}=41)$; with a graduate degree $(77.5 \% ; \mathrm{n}=62)$; with an average experience time as a nurse of 10.6 years $( \pm 6.7)$; working in the institution for a period of less than or equal to five years (average of $5.2 \pm 4.4$ years). Regarding the shift and the institution, $33.8 \%(n=27)$ worked in the morning shift and $41.3 \%(n=33)$ in ECU, respectively.

Most nurses do not consider workplace violence to be normal or intrinsic to their work $(85.0 \% ; n=68)$ and assess that the institution considers this type of violence to be a very important issue (50.0\%; $n=40)$. The risk factors for this condition were diverse and related to multifaceted aspects. It is noteworthy that nurses reported suffering more verbal abuse $(90 \% ; 72 / 80)$ than physical violence $(17.5 \% ; 14 / 80)$, and this was statistically significant ( $p$ $<0.0001)$ by the chi-square test.

Table 1 - Characteristics and consequences of physical violence and verbal abuse suffered by nurses working with risk stratification ( $n=80$ ), Campo Grande, Mato Grosso do Sul, Brazil, 2019

\begin{tabular}{lcc}
\hline Characteristics/consequences & $\begin{array}{c}\text { Violence/Abuse } \mathbf{n}(\mathbf{\%}) \\
\text { Physical (n=14) }\end{array}$ & Verbal (n=62) \\
\hline Number of episodes of violence/abuse in the last 12 months & & \\
1 & $8(57.1)$ & $4(5.6)$ \\
2 & $1(7.4)$ & $7(9.7)$ \\
3 & - & $10(13.9)$ \\
$\geq 4$ & $3(21.4)$ & $41(56.9)$ \\
Do not know or did not answer & $2(14.3)$ & - \\
Conduct taken in the face of the incident* & & \\
Informally notified those entitled to the institution & $8(57.1)$ & $25(34.7)$ \\
Told his or her family/friends & $5(35.7)$ & $31(43.1)$ \\
Lawsuit opened & $5(35.7)$ & $4(5.6)$ \\
There was no conduct & $3(21.4)$ & $17(23.6)$ \\
Asked the person to stop & $3(21.4)$ & $34(47.2)$ \\
Informally communicated the act of violence to his or her superiors & $3(21.4)$ & $46(63.9)$ \\
Told colleagues & $2(14.3)$ & $44(61.1)$ \\
Asked for help from the union/association/council & $1(7.1)$ & $3(4.2)$ \\
Other & $1(7.1)$ & $4(5.6)$ \\
Requested transfer & - & $4(4.2)$ \\
Investigation on the cause of the incident & & \\
No & $8(57.1)$ & $51(70.8)$ \\
Yes & $5(35.7)$ & $10(13.9)$ \\
Do not know or did not answer & $1(7.1)$ & $11(15.3)$ \\
Withdrawal from work after the incident & & \\
No & $13(92.9)$ & $69(95.8)$ \\
Yes & $1(7.1)$ & $3(4.2)$ \\
\hline Note: *Multiple-choice question. & &
\end{tabular}

Among the victims (Table 1), there were 212 (average of 3.41 \pm 2 ) episodes of verbal abuse, against at least 24 instances of physical violence in the last 12 months (the answer "does not know or did not answer" made the exact count impossible). The second type of aggression was more frequently brought to court $(35.7 \%)$ than the first $(5.6 \%)(p<0.001)$.

Comparing physical violence and verbal abuse, as shown in Figure 1, patient companions were the greatest perpetrators of verbal harassment $(43.7 \% ; \mathrm{p}<0.001)$, while patients themselves were the main aggressors in physical violence (58.3\%; $p=0.05$ ). In most episodes of aggression, no action was taken, however, the police was more often called in cases of physical violence 

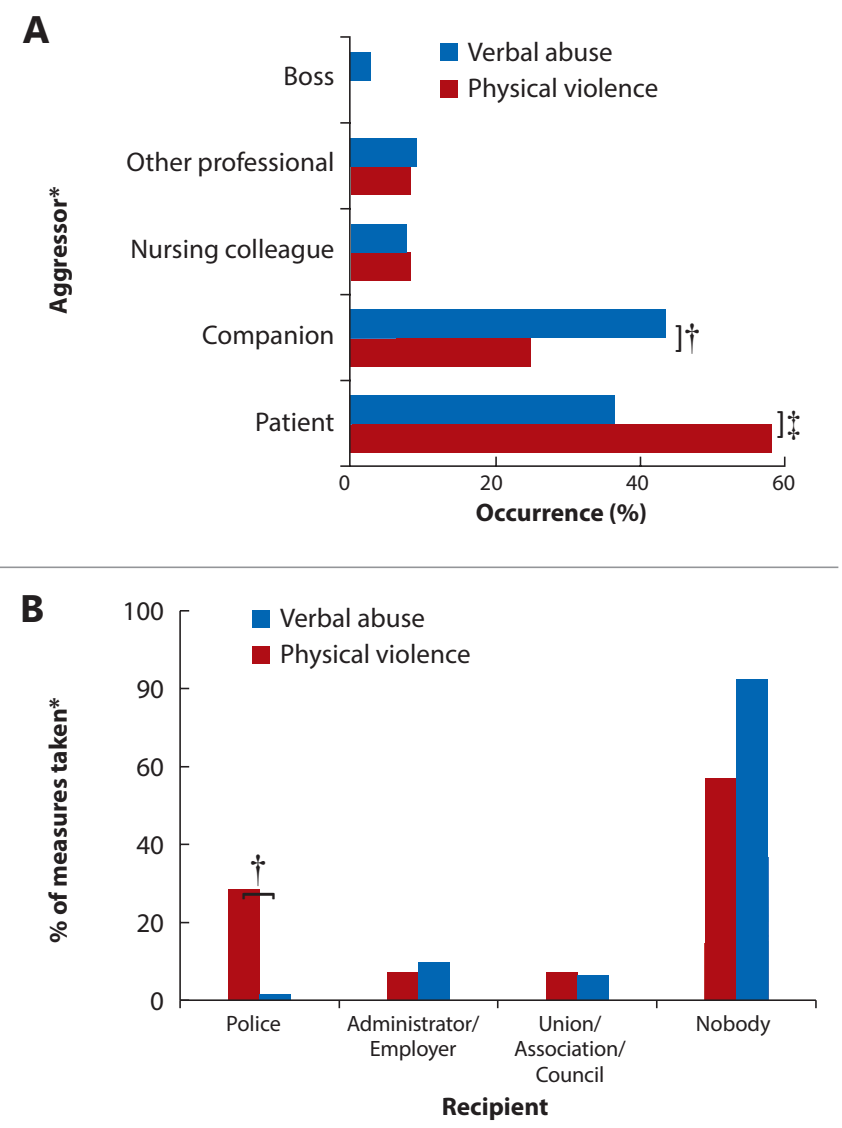

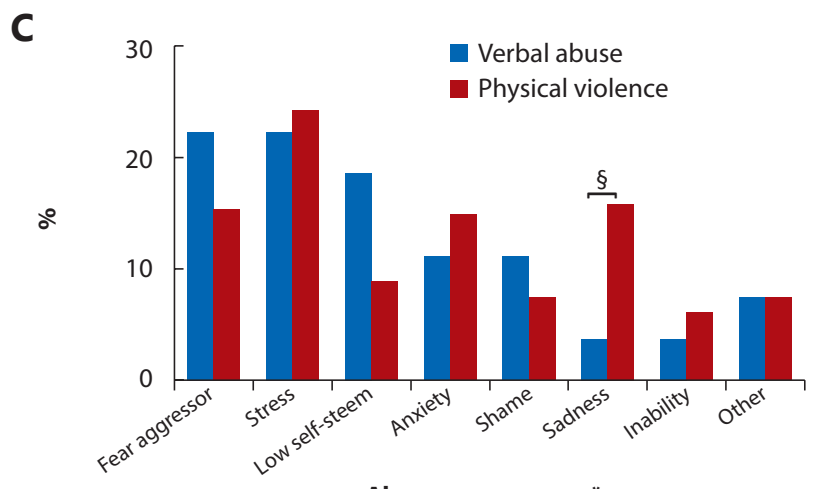

Abuse consequence*

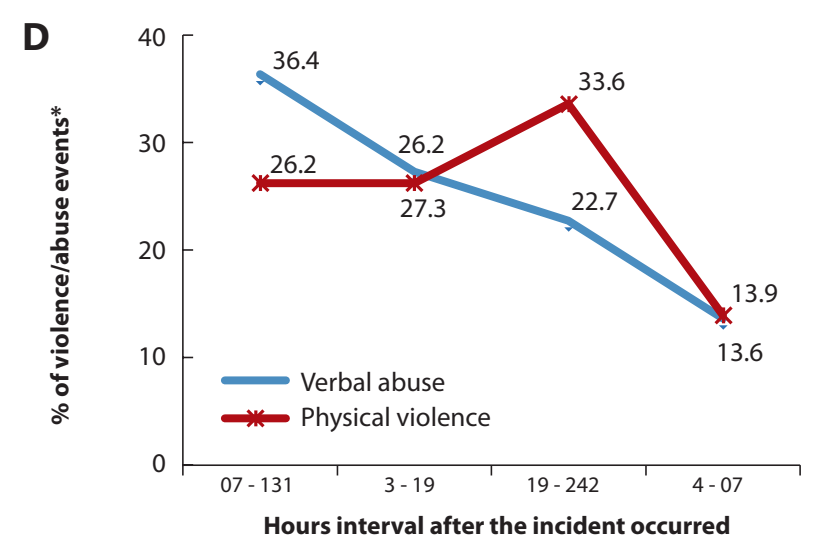

Note: *Multiple-choice question; $t p<0.001$ and $\neq p=0.05$ by Fisher's exact test; $\S P=0.0126$ by the chi-square test.

Figure 1- Aspects related to physical violence and verbal abuse, according to: $(A)$ aggressor; (B) authority to provide a response; (C) consequences of violence to the victim; and (D) period of the day (24 hours) when the violent events occurred ( $\mathrm{n}=80$ ), Campo Grande, Mato Grosso do Sul, Brazil, 2019

Table 2 - Association between sociodemographic characteristics and physical and verbal violence ( $\mathrm{n}=80$ ), Campo Grande, Mato Grosso do Sul, Brazil, 2019

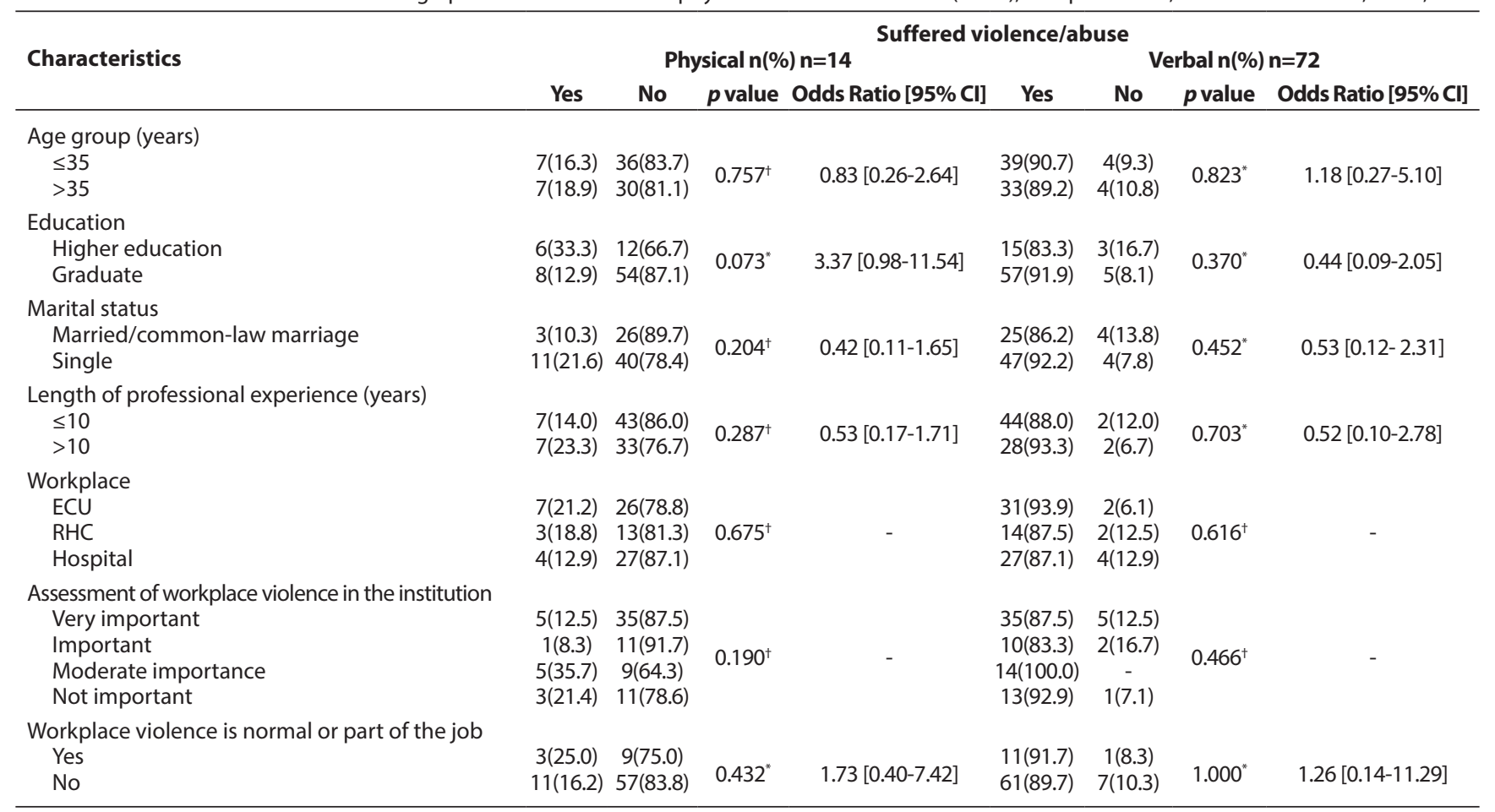

Note: *Fisher's exact; tchi-square; Cl: confidence interval; ECU: Emergency Care Unit; RHC: Regional Health Center. 
(1.6\%) than verbal abuse $(28.6 \% ; p<0.001)$. Fear of the aggressor $(15.3 \%)$, anxiety $(14.9 \%)$ and sadness $(15.8 \%)$ were the main consequences of verbal abuse. However, only the latter differed statistically from physical violence $(\mathrm{p}=0.0126)$. Regarding physical violence, fear of the aggressor (22.2\%), stress (22.2\%) and low self-esteem (18.5\%) were the majority among the consequences. Regarding the time of the incident, globally, it can be said that physical violence occurred predominantly in the morning, while verbal abuse occurred in the early evening.

Concerning the association between sociodemographic characteristics and physical violence and verbal abuse (Table 2), there is evidence of statistical difference between: (i) length of work experience with the occurrence of physical violence at work, as the odds ratio for professionals with up to five years of performance in the institution to experience physical violence is $74 \%$ less than for employees with work experience of more than five years ( $O R=0.26 ; 95 \% \mathrm{Cl}: 0.08-0.86 ; \mathrm{p}=0.029)$; and (ii) nurses' sex with the occurrence of verbal abuse at work, since the odds ratio for women to suffer verbal violence is 5.83 times higher than for men (OR=5.83; 95\% Cl: 1.26-27, 08; $\mathrm{p}=0.026)$.

There was also a significant association between the feeling of security in the workplace and physical violence in the institution in the past 12 months. Victims of physical violence present a lower level of safety $(p=0.017)$.

\section{DISCUSSION}

\section{Verbal abuse}

The factors related to the occurrence of verbal abuse were being female, working at night, not pressing charges about the harassment, and dealing with patients' companions. As a main consequence there is sadness, which was statistically significant in relation to verbal abuse.

Some factors are identified as contributing to the occurrence of verbal abuse, namely: low quality of care; quantity and quality of human resources, materials and equipment; defective communication between nurse and client, providing incorrect or incomplete information; hostility ${ }^{(12)}$; mechanized communication $^{(13)}$; and patient referral to other network services ${ }^{(5)}$. Being a witness of verbal abuse and being a victim of physical violence are also associated with being a victim of verbal abuse ${ }^{(14)}$.

In this study, nurses who suffered verbal abuse dealt with what happened informally and did not report it. This conduct may be associated with the fact that punishment for this type of harassment is milder when compared to physical violence. Therefore, there is a tendency to accept insults without the aggressor being legally penalized. In contrast, the feeling of impunity allows the aggressor to verbally and freely abuse $\mathrm{e}^{(15)}$; and the lack of resolution also causes charges to be dropped ${ }^{(16)}$, as demonstrated in a study carried out in Pakistan, where $62 \%$ of the reported cases of verbal aggression had no consequences for the aggressor ${ }^{(15)}$.

Furthermore, underreporting is a present phenomenon in this theme. A study carried out in $\operatorname{Iran}^{(17)}$ demonstrated that $60.5 \%$ of the professionals did not report episodes of violence that occurred, and more than half of them (52\%) stated that reporting was useless. The lack of report models for this purpose, the fear of retaliation or persecution, and the lack of management support are also factors that make reporting difficult ${ }^{(4,16)}$.

Although the investigated nurses consider that violence is not normal and is not part of their job, verbal abuse was rarely (5.6\%) brought to court. This finding is probably associated with familiarity with this phenomenon, which occurs more frequently during work activities ${ }^{(12,18)}$.

When the association between types of aggression and sociodemographic variables was made, it was found that women suffer almost six times more verbal abuse than men $(p=0.026)$. In this context, it is worth noting that nursing is a predominantly female profession, which is historically linked to submission. Even in the face of social struggles for sex equality ${ }^{(19)}$, there is a naturalization of inequality between the sexes and a predominance of chauvinism, an ideology that values the male figure as a leader ${ }^{(20)}$.

Women are more vulnerable to suffering all types of aggression, even when they perform the same function as men in similar occupational contexts ${ }^{(21)}$. Men and women normally behave differently when faced with the threat of violence. Men are able to avoid a violent episode when they raise their voice, while women are prone to develop feelings of distress and hurt with greater intensity. The female team is able to avoid a violent episode when it retreats before the aggressor, adopting a harmless behavior, an idea that reflects what is socially expected of the female sex ${ }^{(18)}$.

Patient companions were the main perpetrators of verbal abuse (86.1\%), while patients themselves were the aggressors in physical violence cases (100\%). This occurred similarly in other Brazilian studies, which point out patients' family members, patients and co-workers as the main sources of violence ${ }^{(14,22)}$. In particular, regarding companions, it may be related to the frustration associated with the expectation of a quick and resolutive service; and/or when patients are unable to express themselves, as is the case with child and elderly patients, so their dissatisfaction with institutional characteristics and a deficit of professionals is expressed to the risk categorizing nurse, a professional who is easily accessed.

\section{Physical violence}

Having more than five-years' work experience, working in the morning, and facing patients as the perpetrators of violence were statistically-related factors to the occurrence of physical violence, which was relatively more often brought to court.

Patients were the perpetrators of physical violence in all cases found in this study. It may be related to disagreement regarding the risk category in which they were stratified, especially in non-urgent situations; as well as in situations when patients are referred to other services of the healthcare network, as occurs in hospitals ${ }^{(5)}$. Moreover, having previous history of violence, consuming illicit drugs, carrying a firearm, and being under the influence of alcohol are factors that are associated with aggressive and uncontrolled behaviors ${ }^{(23)}$.

Physical violence was more often brought to court when compared to verbal abuse. This can be explained by the fact that physical violence is easily recognized and impactful, especially when injuries occur. Despite this, some studies reveal that the consequences for the aggressor are insignificant, such as verbal warnings, or the absence of criminal sanction altogether, which provokes the feeling that it is useless to file a complaint ${ }^{(15,24)}$. 
In this study, having five or more years of work experience as a nurse was a risk factor for the occurrence of physical violence. These findings are different from the reality found in national ${ }^{(19)}$ and international ${ }^{(24-25)}$ studies. They were developed in emergency sectors, which record the highest number of employees with less than five years of experience.

However, a study carried out in the Netherlands ${ }^{(26)}$ showed that nurses in risk categorization with longer work experience tend to refer non-urgent patients to other health services, such as primary care centers integrated with the emergency service. They were associated with longer patient waiting times, and with low or non-urgent categorizations. This is possibly because these nurses are more knowledgeable and make screening decisions and judgments more confidently, assuming more clinical risks than nurses with less years of experience in risk categorization. As seen, referring patients to other services or increasing the waiting time for care are factors that can trigger aggressiveness.

As for the time of occurrence of violent events, verbal abuse occurs mainly in the early hours of the night, while physical violence tends to happen in the morning. Physical violence in the morning is related to health conditions that result in absence from work or school. Due to illness, there is a demand for healthcare services in search of resolution, with the expectation of formally justifying the absence from work or school. However, when faced with delay in care and shortage of professionals, combined with stress due to their health condition, some patients can become aggressive.

International studies indicate the night shift as the most susceptible one to episodes of violence $(34.1 \%)^{(15)}$. This is probably due to reduced staff(27) and the fact that professionals work overtime - a very common circumstance in risk categorization environments -, which is linked to work overload and tiredness, respectively ${ }^{(28)}$. In addition, the night time has an increased flow of people because Basic Health Units are not open during this shift and most people do not work at this time. Thus, the demand for emergency services in search of resolution can be greater, while the service capacity is theoretically lower.

In this study, the main consequence for nurses who suffered verbal abuse is sadness. The physically attacked ones develop fear of the aggressor, stress and low self-esteem, on most cases. Nurses who experience physical and verbal aggression concurrently may present physical and psychological manifestations that generate an intention to leave the profession ${ }^{(14)}$.

Another study with screening nurses obtained similar results ${ }^{(18)}$. After violent incidents, professionals experienced feelings of guilt and inadequacy for not knowing how to deal with the incident or for the stance they took, for fear of the aggressor to return, and for fear of becoming a victim again. In addition, there are negative repercussions on mental and physical health, social interactions and professional implications, such as loss of interest and concentration at work and mechanized interactions with patients and other professionals ${ }^{(13)}$.
Nurses who are victims of physical violence had less feeling of security at work $(p=0.017)$. This feeling of security may be related to the lack of support and resolution of the legal system when the complaint is made ${ }^{(16)}$; the installation of insufficient safety measures at work ${ }^{(24)}$; the lack of measures to combat violence ${ }^{(29)}$; and the lack of training by both professionals and management to identify and deal with violence ${ }^{(27)}$.

\section{Study limitations}

The limitations of this study were the sample size, due to the large number of nurses who had worked at the institutions for less than one year. Some nurses gave up participating with the justification that the instrument was extensive, pointing out the need for reformulation for further studies. Institutional characteristics were little explored and employment relationships were not covered by the data collection instrument. The characteristics of violence in different emergency establishments (ECU, RHC, and Hospital emergency rooms) were little explored and the consequences of different types of violence could have been investigated separately.

\section{Contributions to nursing and health}

The results of this study can support the planning of actions to reduce workplace violence against nurses in patient risk category stratification environments across the country. The reality of the public health care network in the studied location is similar to most Brazilian municipalities. In addition, it is necessary to invest in training programs, for all professionals, to propose the management of violent incidents in the workplace; analyze the institutional risk factors that contribute to occupational violence, as done in this study, in order to promote more assertive and evidence-based actions; and invest in educating the population to clarify the functions of the urgency and emergency network.

\section{CONCLUSION}

This study analyzed the main characteristics, related factors, and consequences of physical violence and verbal abuse against nurses who work in risk categorization. It is concluded that such violence is influenced by institutional, professional and client aspects. Facing this problem includes improving service capacity, working conditions and institutional policies for permanent education, in addition to educating and sensitizing service users and their companions. Future research will be able to assess the impact of these interventions.

\section{FUNDING}

This study was financed in part by the Coordenação de Aperfeiçoamento de Pessoal de Nível Superior - Brasil (CAPES) - Finance Code 001.

\section{REFERENCES}

1. International Labour Organization. Convention 190 [Internet]. Genebra: ILO. 2019 [cited 2019 Oct 22]. Available from: https://www.ilo.org/ dyn/normlex/en/f?p=NORMLEXPUB:12100:0::NO::P12100_ILO_CODE:C190 
2. Organización Mundial de la Salud. Directrices marco para afrontar la violência laboral em el sector de la salud [Internet]. Genebra: OMS. 2002 [cited 2019 Oct 22]. Available from: https://www.ilo.org/wcmsp5/groups/public/---ed_dialogue/---sector/documents/publication/wcms_160911.pdf

3. Farrell GA, Bobrowski C, Bobrowski P. Scoping workplace aggression in nursing: findings from an Australian study. J Adv Nurs. 2006;55(6):778-87. doi: 10.1111/j.1365-2648.2006.03956.x

4. Kowalenko T, Cunningham R, Sachs CJ, Gore R, Barata IA, Gates D, et al. Workplace violence in emergency medicine: current knowledge and future directions. J Emerg Med. 2012;43(3):523-31. doi: 10.1016/j.jemermed.2012.02.056

5. Freitas RJM, Pereira MFA, Lima CHP, Melo JN, Oliveira KKD. Violence against nursing professionals in the embracement sector with risk classification. Rev Gaúcha Enferm. 2017;38(3):1-8. doi: 10.1590/1983-1447.2017.03.62119

6. Partridge B, Affleck J. Verbal abuse and physical assault in the emergency department: Rates of violence, perceptions of safety, and attitudes towards security. Australas Emerg Nurs J. 2017;20(3):139-45. doi: 10.1016/j.aenj.2017.05.001

7. Spector PE, Zhou ZE, Che XX. Nurse exposure to physical and nonphysical violence, bullying, and sexual harassment: a quantitative review. Int J Nurs Stud. 2014;51(1):72-84. doi: 10.1016/j.jpurstu.2013.01.010

8. Conselho Regional de Enfermagem do Estado de São Paulo. Conselho Regional de Medicina de São Paulo (CREMESP). Sondagem com Médicos e Profissionais de Enfermagem [Internet]. São Paulo: COREN. 2017 [cited 2019 Oct 22]. Available from: https://www.lo.org/ wcmsp5/groups/public/---ed_norm/---relconf/documents/meetingdocument/wcms_711244.pdf

9. Mantzouranis G, Fafliora E, Bampalis VG, Christopoulou I. Assessment and Analysis of Workplace Violence in a Greek Tertiary Hospital. Arch Environ Occup Health. 2015;70(5):256-64. doi: 10.1080/19338244.2013.879564

10. Piquero NL, Piquero AR, Craig JM, Clipper SJ. Assessing research on workplace violence, 2000-2012. Aggression and Violent Behavior. 2013;18(3):383-94. doi: 10.1016/j.avb.2013.03.001

11. Morais Filho LA. Violência ocupacional contra profissionais de saúde em um hospital de urgência Natal/RN. [Dissertação] [Internet]. Natal: Universidade Federal do Rio Grande do Norte; 2009 [cited 2019 Oct 22]. Available from: https://repositorio.ufrn.br/jspui/ bitstream/123456789/14685/1/LuisAMF_DISSERT.pdf

12. Angland S, Dowling M, Casey D. Nurses' perceptions of the factors which cause violence and aggression in the emergency department: a qualitative study. Int Emerg Nurs. 2014;22(3):134-9. doi: 10.1016/j.ienj.2013.09.005

13. Hassankhani H, Parizad N, Gacki-Smith J, Rahmani A, Mohammadi E. The consequences of violence against nurses working in the emergency department: a qualitative study. Int Emerg Nurs. 2018;39:20-5. doi: 10.1016/j.ienj.2017.07.007

14. Tsukamoto SAS, Galdino MJQ, Robazzi MLCC, Ribeiro RP, Soares MH, Haddad MCFL, et al. Occupational violence in the nursing team: prevalence and associated factors. Acta Paul Enferm. 2019;32(4):425-32. doi: 10.1590/1982-0194201900058

15. Zafar W, Siddiqui E, Ejaz K, Shehzad MU, Khan UR, Jamali S, et al. Health care personnel and workplace violence in the emergency departments of a volatile metropolis: results from Karachi, Pakistan. J Emerg Med. 2013;45(5):761-72. doi: 10.1016/j.jemermed.2013.04.049

16. Wolf LA, Delao AM, Perhats C. Nothing changes, nobody cares: understanding the experience of emergency nurses physically or verbally assaulted while providing care. J Emerg Nurs. 2014;40(4):305-10. doi: 10.1016/j.jen.2013.11.006

17. Fallahi-Khoshknab M, Oskouie F, Najafi F, Ghazanfari N, Tamizi Z, Afshani S. Physical violence against health care workers: a nationwide study from Iran. Iran J Nurs Midwifery Res. 2016;21(3):232-8. doi: 10.4103/1735-9066.180387

18. Ramacciati N, Ceccagnoli A, Addey B. Violence against nurses in the triage area: an Italian qualitative study. Int Emerg Nurs. 2015;23(4):27480. doi: 10.1016/j.ienj.2015.02.004

19. Vasconcellos IRR, Griep RH, Lisboa MTL, Rotenberg L. Violência no cotidiano de trabalho de enfermagem hospitalar. Acta Paul Enferm. 2012;25(2):40-7. doi: 10.1590/S0103-21002012000900007

20. Lucena KDT, Deninger LSC, Coelho HFC, Monteiro ACC, Vianna RPT, Nascimento JA. Analysis of the cycle of domestic violence against women. J Hum Growth Dev. 26(1):139-46. doi: 10.7322/jhgd.119238

21. Lanthier S, Bielecky A, Smith PM. Examining Risk of Workplace Violence in Canada: A Sex/Gender-Based Analysis. Ann Work Expo Health 2018;62(8):1012-20. doi: 10.1093/annweh/wxy066

22. Vasconcellos IRR, Abreu AMM, Maia EL. Violência ocupacional sofrida pelos profissionais de enfermagem do serviço de pronto atendimento hospitalar. Rev Gaúcha Enferm. 2012;33(2):167-75. doi: 10.1590/S1983-14472012000200024

23. Rodríguez VA, Paravic TM. Un modelo para investigar violencia laboral en el sector salud. Rev Gaucha Enferm. 2013;34(1):196-200. doi: $10.1590 /$ S1983-14472013000100025

24. Ahmed AS. Verbal and physical abuse against Jordanian nurses in the work environment. East Mediterr Health J [Internet]. 2012 [cited 2019 Nov 04];18(4):318-24. Available from: https://www.ncbi.nlm.nih.gov/pubmed/22768692

25. Zhang L, Wang A, Xie X, Zhou Y, Li J, Yang L, et al. Workplace violence against nurses: A cross-sectional study. Int J Nurs Stud. 2017;72:8-14. doi: 10.1016/j.jinurstu.2017.04.002

26. van der Linden MC, Meester BE, van der Linden N. Emergency department crowding affects triage processes. Int Emerg Nurs. 2016;29:27-31 doi: 10.1016/j.ienj.2016.02.003

27. Edward KL, Ousey K, Warelow P, Lui S. Nursing and aggression in the workplace: a systematic review. Br J Nurs. 2014;23(12):653-4, 656-9. doi: 10.12968/bjon.2014.23.12.653 
28. Jafree SR. Workplace violence against women nurses working in two public sector hospitals of Lahore, Pakistan. Nurs Outlook. 2017;65(4):420-7. doi: 10.1016/j.outlook.2017.01.008

29. Ashton RA, Morris L, Smith I. A qualitative meta-synthesis of emergency department staff experiences of violence and aggression. Int Emerg Nurs. 2018;39:13-9. doi: 10.1016/j.ienj.2017.12.004 